\title{
TIME, SPACE, AND RATIONALITY: RETHINKING POLITICAL ACTION THROUGH THE EXAMPLE OF MONTREAL'S STUDENT SPRING 1
}

Julie-Anne Boudreau and Mathieu Labrie

Institut National de la Recherche Scientifique, Centre Urbanisation, Culture, Société, Montréal

\section{Abstract $^{1}$}

Because of a changing relationship with time, space, and affect in a more urbanized world, political actions and social movement practices have transcended the modern, state-oriented logic of action. Following this claim, this paper questions a specifically urban way of acting politically. To answer this question, we need to begin by "looking" for politics in the kinds of places that political scientists generally overlook for political analysis. Understanding the urban logic of political action cannot come solely from an observation of political campaigns, ideologies, political organizations, or interviews with social movement leaders. Using the 2012 student strike in Montreal as our focus, we are taking a different analytical angle that focuses more closely on the personal experience of participation, the personal trajectories of the participating students and the effect of this intense mobilization. This research project uses biometric tools, spatial data and qualita-

1 We are most grateful to the students who generously shared their experience with us during this research. We would like to thank our research team: Alexia Bhéreur-Lagounaris, Maude Séguin-Manègre, Denis Carlier, Alex Roy and Claudio Ribeiro. The biometric, GPS, and video equipment was paid for thanks to a grant from the Canadian Foundation for Innovation. tive data to investigate political participation and its relation to the city space.

Keywords: Social movement, urbanity, Montreal, biometrics, emotions

Tiempo, Espacio y Racionalidad: Consideraciones sobre la Acción Política a través del Ejemplo de la Primavera de lxs Estudiantes de Montreal

\section{Resumen}

Debido a los cambios en las relaciones con el tiempo, el espacio y el afecto en un mundo más urbanizado, las acciones políticas y las prácticas de los movimientos sociales han trascendido la lógica de acción moderna y centrada en el estado. Siguiendo este argumento, este artículo cuestiona la forma específicamente urbana de actuar políticamente. Para ello es necesario comenzar por "buscar" prácticas políticas en los lugares que lxs politólogxs suelen ignorar. Para entender la lógica urbana de acción política no basta con solamente observar campañas, organizaciones e ideologías políticas, o con entrevistar a líderes de movimientos sociales. Utilizando la huelga de estudiantes de 
Montreal en 2012 como caso, aquí tomamos una perspectiva analítica diferente que enfatiza la experiencia personal de participación, las trayectorias personales de lxs estudiantes que participaron y el efecto de esa intensa movilización. Este proyecto de investigación usa herramientas biométricas, análisis espacial y datos cualitativos para estudiar la participación política y su relación con el espacio de la ciudad.

Palabras clave: movimiento social, urbanidad, Montreal, biométrica, emociones

\section{Introduction}

In February 2012, Montreal was swept by a massive mobilization of students opposed to the tuition fee increase announced by the provincial government of Jean Charest. The government planned a $75 \%$ increase in tuition fees over five years. What occurred was the longest and largest student strike in the history of Quebec. This movement quickly evolved into an unprecedented "social crisis" (Chiasson-LeBel, 2012). More than 300,000 students were mobilized into a struggle against the government that lasted more than eight months. In Montreal, hundreds of demonstrations, rallies, and economic disruption activities were held daily between February and August 2012.

Though the protest events were mainly organized by the three largest student unions in the first weeks of the conflict, it rapidly became a more horizontal and bottom-up movement. Faced with a stubborn government, students turned to confrontation and direct action (Savard and Cyr, 2014). Their repertoire was diversified, including artistic expression and active appropriation of urban spaces and the imaginary (Labrie, 2015). Police reaction was brutal, leading to a record 3,500 arrests; some three and a half times more than over the previous twenty years (Dupuis-Déri et al., 2013).

Montreal has a long history of popular mobilisation and is known as the epicenter of Quebec's Quiet Revolution which took place in the $60 \mathrm{~s}$ and $70 \mathrm{~s}$ (Mills, 2011). What is less recognized however is the role it played in the Black power movements over the same period (Austin, 2013). Montreal's well-organised civil society has been active in the environmental movement (Fontan, Hamel and Morin, 2012) and fighting against corporate interests in housing issues (Helman, 1987). The city was also mentioned by non-native interviewees as being a uniquely "public" and "creative" city where people can express their opinion and rely on the city's strong trade-union movement.

Montreal is unique among Canadian cities for the bilingual character which shapes its cultural and political landscape (Germain and Rose, 2000). This linguistic situation is reflected by the presence of two major English-speaking universities and two important French-speaking universities all of which are located in downtown Montréal. With a post-secondary student population of over 260000 individuals, Montreal is one of the most important student cities in North America.

Scientific, political, and artistic literature flourished during and after these events, but here, we are offering a different analytical angle that focuses more on the personal experience of the participating students than on the outcome of the campaign (Stolle et al., 2013), its ideology (Diaz-Parra and Candon Mena, 2015), the student-police relations (Dupuis-Déri, 2013), the organization of the movement (Martin, 2013), press coverage, collective strategies (Labrie, 2015) and the historical roots of the movement (Simard, 2013). We were intrigued by the personal trajectories of participating students and the effect that this intense mobilization had on their spatial relationship with the city.

Using data collected in 2013 from youths who participated in the 2012 Montreal demonstrations, this paper seeks to highlight the changing relationship with time, space, and rationality and its effect on political action in the contemporary urban world. Theoretically, the paper seeks to establish whether there is a specifically urban way of acting politically. To better understand these political forms, this paper argues that we need to "look" for politics in places that political scientists would not generally choose for political analysis. Understanding the urban logic of political action cannot come from an observation 
of political campaigns, ideologies, political organizations, or interviews with social movement leaders.

The ethnographic work presented in this article takes a different approach, delving into the common symbols that structure the individual and collective imaginary including the political gestures of youths and the implicit "grammar" that gives meaning to these multi-faceted gestures and feelings. This article argues that living in an urban world transforms our conception of time, space, and rationality, and that these emerging conceptions which are based on non-linearity, mobility, and affectivity have an important effect on political action.

In the 1980s and 1990s, studies of urban social movements were largely inspired by Castell's work (1973). He described the city as being a social space marked by the contradictions of capitalism and where "new forms of social conflict are directly linked to the collective organization of ways of life" (Castells, 1973: 12 , translation is ours). In this early version, Castells is concerned with assessing whether such movements have socially-transformative and revolutionary potential. His analysis is primarily focused on how to overcome the structural contradictions of capitalism.

A decade later, Castells progressively abandoned this discussion to focus instead on the production of a city based on use-value, autonomous local cultures and decentralized participatory democracy (Castells, 1983). Other key texts on urban movements discussed the pros and cons of urban mobilization outside of the factory in the same decade however, generally in reference to the contradictions of capitalism (Harvey, 1984; Pickvance, 1985; Fainstein and Fainstein, 1985). The work of Cox (1998) was particularly influential in trying to outline the specificities of local spaces of dependence over spaces of engagement, arguing that local politics was specifically due to geographically-dependent relations.

This scalar thinking was further developed through Jessop and Brenner's re-reading of Poulantzas and Lefebvre's state theories. They explain how the state consists of a field of various tensions and forces. Local state actors are entangled in a web of influence and coercion from state actors on various scales. However, with the forces of global capitalism increasingly significant since the 1970 s, the city-regional scale has become a key locus of power. Brenner suggests that it is on this scale that the state strategically and selectively devises spatial projects to respond to the crises generated by global neoliberalism.

The urban, not only as a place (the city and its suburbs), or as a scale (the local), but rather as a "way of life" and an ontology, is where more issues are problematized and performed. This therefore largely defines the very meaning of the political process. Magnusson (2011) suggests that this requires "seeing like a city." What he means is that it might be more fruitful to understand politics as processes of self-governance with multiple centers rather than through a sovereign and centralized state. The best metaphor for these multiple processes of self-governance is the city itself. Politics exceeds the formal processes bounded by state sovereignty-with urban ways of life illustrating this vividly. Magnusson's goal was to define the contours of a new ontology for the political, which takes inspiration from the way people live together and "make it work" in cities.

World urbanization implies that we develop new types of relationships with space, time, and affect more prominently under the modern state system. It is now very difficult to conceive of urban struggles as being solely local. In activists' as well as theorists' imaginaries, local issues are generally globally-connected either in terms of discursive framing resources, causal explanations, or consequences.

\section{A changing relation to time, space and rationality}

More than a modern conception of progressing time, this research shows that students were acting according to an "urban" conception of instantaneous, simultaneous, non-cumulative time composed of thousands of interrelated situations. ${ }^{2}$ We were more

2 The city has long been associated with such non-linear time involving unpredictability, ephemerality, newness, fluid identities, and casualness towards the future (Lefebvre, 1970; Toffler, 1970; Virilio, 1986; Bauman, 2005). 
interested in understanding the multiple moments that made-up the 2012 spring demonstrations in Montreal, than in evaluating their political significance on the scale of societal history. This is because the students expressed a non-linear conception of time, a culmination of multiple situations that were dominated by the here and now and where tactics were more valued than strategies.

We focused on situations that best articulate this temporal element of the "moment" with the spatial element of "place". According to Goffman (1959), a situation is necessarily interactive, involving verbal and non-verbal exchanges between at least two individuals and between an individual and the material and symbolic objects the create the location. Life is made of millions of situations, however those that are of interest to us here are the ones that are significant to the individual.

When analysing the hundreds of situations we heard during our interviews, we sought to highlight the role played by the youth's mode of orientation when looking to the future (Munn, 1992: 106). How important is the future to them (casualness, anticipation, anxiety, etc.)? Do they speak of a near and/or indefinite future? We also wanted to characterize their conception of change. People normally decide to be politically active because they want to affect the world around them. How did the interviewees conceive of the effects of their acts and on what scale do they view them (regarding themselves, the group, society and the abstract future)? How do they define social change? We highlighted the sequence of these gestures in situations of action. How did our interviewees act and react? What was the role played by strategic thinking and planning?

To understand why the campaign lasted so long, despite some of the risks associated with it, we felt that we needed to look beyond strategic action and the analysis of power relations. This is not to say of course, that power was evenly distributed among students or between them and with the government. We wanted to see whether political action was characterized as being more intuitive or affective rather than strategic, ideological, or rational.
Interest in the emotional aspects of political action and social movement research re-emerged in the 1980s after more than twenty years of dormancy. During this period, resource mobilization theory took over from the previously preferred crowd-based interpretations which perceived emotions as being irrational and "the driving force of virtually all political action that occurred outside normal institutions" (as explained by Goodwin and Jasper, 2006: 612). As social movement theory took a "cultural turn" in the 1980s, emotions came back under the analytical gaze with a poststructuralist framework that acknowledged identity construction as a key social process (Deverteuil, 2014; Jasper, 2011).

Just as emotions were coming back into the picture for social movement analysis, the nature and construction of individuals' emotional relationship to urban spaces and places was becoming central to broader multidisciplinary literature. Examples of this include research on place-making and urban marketing and the emotional experiences and consumption behavior of tourists (Hosany et al., 2015). Research also returned to using a phenomenological approach (following Lynch, 1960) to understand peoples' relation with urban landscapes. This body of literature participated in the development of important concepts such as sense of place, place attachment, place dependence and place identity. As Manzo concluded, researchers "demonstrated how affective relationships to places (1) encompass a broad range of physical settings and emotions; (2) are an ever-changing, dynamic phenomenon; (3) are both unconscious and conscious; and (4) exist within a larger socio-political milieu" (Manzo, 2003: 48).

Building on this, we focused on the forces that circulate between bodies in space, producing specific situations of action. Quincy, ${ }^{3}$ for example, speaks of this affective force in these words:

Quincy: Like, what's really awesome about this is when you go into the tunnel, I mean, you can hear yourself. I think we can cross through. Um, we hear it amplified. (...) Like, I

3 All names are fictional. All translations from French-language interviews are ours. 
remember feeling ecstatic, like totally ecstatic, like going through the tunnel and hearing like, just like the vibration of it right? It's just like how loud is it? And people started screaming right? It makes me emotional (weakly, as if he is going to cry).

Quincy was remembering this situation as we were walking together through the tunnel at the corner of Berri and Sherbrooke streets. Rather than analyzing his choice of words to express these emotions, we chose instead to go beyond the oral text and explore the pre-linguistic register. Beyond what the interviewees told us, we wanted to look at the affective forces circulating among the youths during these demonstrations. In these specific situations of action, how did the action unfold?

This situational position meant that we had to analyze this eight-month episode of intense mobilization on a much smaller scale than what the sociology of social movement normally does due to its focus on the closed territorial space of state institutions. This realization led us to explore our interviewees' conceptions of space.

With the intensification of mobility over the past few decades (Sheller and Urry, 2006), peoples' relationship to space is changing. Institutionally, it is increasingly difficult to conceive of public policy as being exclusively attached to a static and enclosed territory. Brenner (2004) has shown how the political process unfolds on multiple scales, while Amin (2004) insists on connections between spaces of political action. On an interpersonal level, the fact that people are increasingly mobile affects how they constitute themselves as political actors (Boudreau, 2009). Moving around means interacting with a broad range of people in many different places. Ontologically, this means people often feel "estranged" and this tends to produce different forms of political engagement. Threats to personal roots (the nation, the community) have long been an important motor of political action. However, the multiplication of reference points brought by mobility practices as well as the development of trans-local networks, brings with it new sources of political engagement. In short, people are adopting a more reticular conception of space as a dynamic collection of significant places.

\section{Pushing methodological boundaries}

To capture these changing relations to time, space, and rationality, we were faced with two methodological barriers. How can we capture relation to time with qualitative data which is always collected postfacto? Similarly, how can we capture the relationship between rationality and affectivity if we rely on interviews that require reconstructing action and emotions through cognitive filtering? In a qualitative interview, a person is asked to speak about their emotions and about what they did, why they did it and how it was done. The subject will inevitably filter their information and organize it rationally to respond to the interviewer's questions. What we wanted instead was access real-time, unfiltered, and spatially-situated data. This is why we used various devices, including mental mapping, biometric data, video, and GPS data.

We asked the interviewee to choose a meeting point in a place that was significant to them. We sat there for roughly 30 minutes talking about why they had decided to participate in the movement. Then we asked the participant to draw a mental map of their "city under strike," identifying the places that were most important to their participation. We then began an improvised walk through the city, during which the interviewee would recall anecdotes and situations as we were visiting the various sites that they had identified. During these two hour walks, the interviewee would wear sunglasses with a built-in camera, filming what they were seeing in addition to wearing a Q-Sensor biometric bracelet. The Q-Sensor translates emotional activity into graphic data by measuring electrodermal activity. ${ }^{4}$ The interviewer also carried a GPS tracker in their bag.

After the walk, the interviewer produced a video montage, synchronizing the audio-video images, GPS, and biometric data. We did not want to interpret this data ourselves (as psychologists would do) and we did not assume that there was a direct relation between

4 With emotional arousal, the brain sends signals to the skin to increase the level of sweating. 
electrodermal activity and emotions or affects. Instead, we met with the interviewee a second time to "give" them back this data. During this meeting, the person would see their synchronized data and comment on their biometric activity. Sometimes a spike in biometric activity was related to the places where an event occurred and at other locations, the interviewee would interpret this activity as being more related to the topic we were discussing at that specific moment during the walk. These second interviews also lasted between two and two and a half hours.

The experience was highly appreciated by our 27 participants. Not only did it enable them to remember situations they may have "forgotten," but it also allowed then to reflect on their involvement and the impact it had on their personal lives. These interviews were subsequently fully transcribed ( 2 meetings per participant) and analyzed thematically. We also constructed a database of the various emotions expressed by the participants regarding their spatial location.

\section{The process of political engagement}

When we analyzed the words used in our interviews to express emotions, we essentially found negative feelings. All of the 27 interviewees, except three, spoke of fear, violence, stress, craziness, anger, and of running away. At least $75 \%$ of them used words such as tension, screams, surprise, war, chaos, blowing up, and aggressiveness. More than $50 \%$ spoke of panic, absurdity, cries, worries, trauma, but also pride. However, when analyzing specific situations of their actions, as well as the way our respondents spoke of their motives for becoming politically engaged, we saw that more positive effects stood out.
We asked our interviewees why they decided to get involved in the movement's activities. In their responses, they insisted on friendship, the confirmation of their identity ("I had leftist tendencies", "I used to be involved"), self-realization ("it is empowering" and "to acquire a kind of strength"). Pleasure, excitement and hope were also mentioned by many (figure 1).

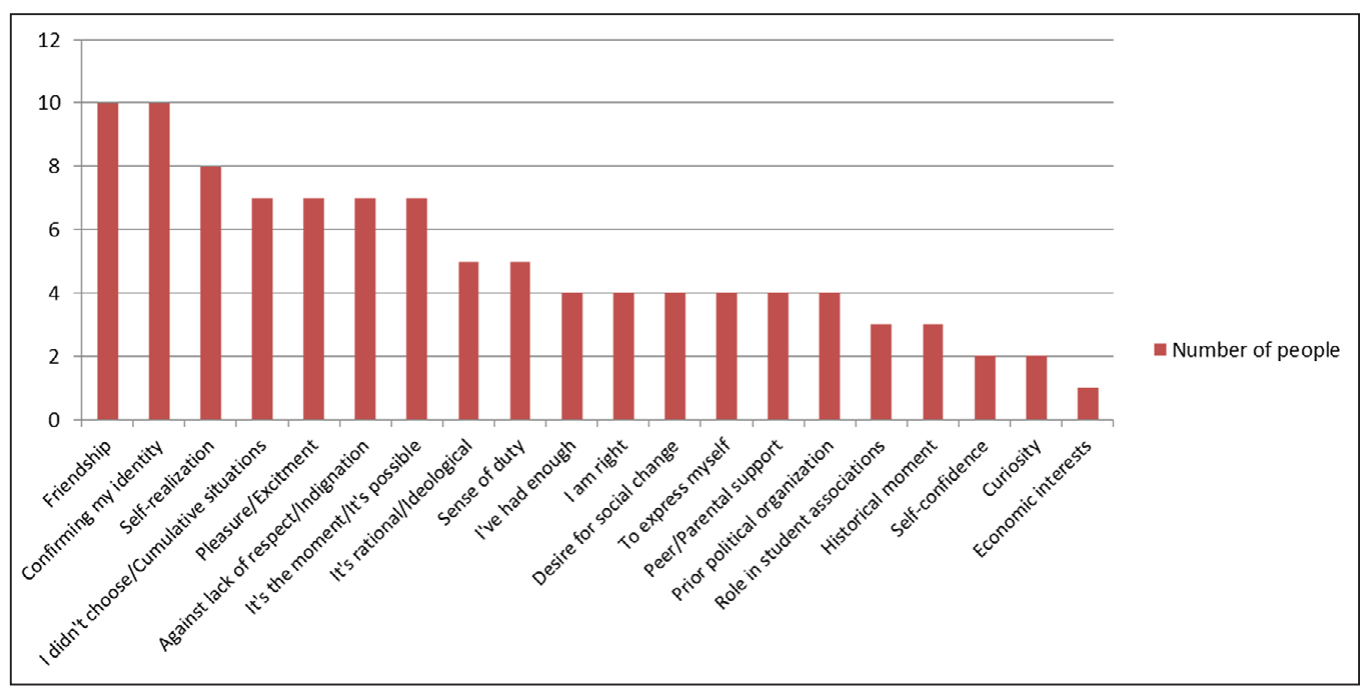

Figure 1. Motives of engagement

These are essentially positive motives. They emphasized an affective relation to their commitment more than a rationally-developed ideological discourse. They described their involvement as an intuitive intertwining of situations, where they did not "decide" at one specific point to become active, they just did. Auyero (2004) pointed to a similar process in his study of a road blockage in Argentina:

'Pace rational action theorists, so fond of instances of calculation and decision-making, there is no moment in which Laura made a plain, make or break, choice to stay on the road, no occasion in which she ran the costs and benefits of possible action plans through a psychic adding machine to decide on a plan that will maximize her investment of energy, both physical and emotional. She was actually sucked into the role of picketer by the interactions she had on the road, inter- 
actions deeply shaped by elements of her own biography. (Auyero, 2004: 431)

However, when we asked our respondents why they had participated in specific activities where they risked being arrested for instance, they tended to use a publicly acceptable and rationalized justification. Ivan, for instance, said: "there was also a hyper-rational process behind all of this, in the sense of how can I get involved, where do I get involved and where is the limit. I don't mean limit in the sense of 'limit', but it was my way of defining myself at the movement." They similarly evoked a sense of duty ("against an unjust state"). Ideological explanations were more forcefully given when explaining their participation in risky activities than when they were asked to speak more generally of their involvement.

However, here again, peer support was central: "I knew I wasn't alone. We were risking something collectively"; "it was not as scary because you're there with people". Even when they felt the need to justify their engagement with publicly acceptable motives (duty, rational political arguments), affective relations remained important. To better capture how these motives worked, we focused on the sequence of gestures in the specific situations of action they reconstructed for us as we were walking with them and when viewing their data during our second meeting.

\section{The unfolding of action situations: Time}

The sequence of gestures (how they acted and reacted in specific moments and places) reveal the subject's non-linear conception of time. The interviewees spoke more of tactics than strategies, which implies immediate reactions in situations of action more than planned gestures. They further emphasized the strong feeling of improvisation during actions. Umberto puts it this way:

I don't feel like it was out of control, like it was chaotic and I feel like decisions were always being made so it was never like, random. It wasn't like a riot out of control. I don't want to suggest that, but I don't feel like there was a clear plan and we were following that plan. I feel like most things were like "now we're going to do this thing; it's kinda... it's pretty spontaneous" and then you would develop a habit around that.

This lack of centralized control was extensively criticized by the media. It was the basis of the government's refusal to recognize the legitimacy of the student actions. Many of the students however greatly valued this "loss of control":

Wajdi: For me, it's crystal clear that if things had been under control, we would have fucked up. In the sense that we had a moment of collective strike. It was a moment when we gave ourselves the means to be asocial on all aspects, through the actions we were taking as much as through the ideas we were juggling. There were many people who dared to think, and say and do things they wouldn't have done otherwise. And these things, if they had been under control, if they would've had to report to someone, it wouldn't have happened.

Interviewer: When you say asocial, you mean outside of society?

Wajdi: Yes, I mean etymologically. So to my view, it is controlling. Yes I think that people had an ethic, a morality, so many things were controlled in that sense. But in the sense of institutional control, no, it was really a moment of chaos. I'm really happy because it opened many possibilities. I saw more stars in people's eyes during this strike than during all my university studies.

These "stars in people's eyes" were associated with a sense of fulfilment during their experience in specific moments and places. We wanted to see whether such situational stories would be balanced by more linear temporalities. This is why we carefully analyzed their feelings on risk-taking, because the notion of "risk" implies an evaluation of the consequences of an act (and thus a linear temporality, a projection of the future as the consequence of the present). When asked if they saw their activities as being risky, they 
mostly did not understand the question at first. They would eventually mention the risks of physical harm in violent confrontations with the police or the risk of being arrested, but very rarely would they speak of a risk to their academic future.

Career plans are an example of linear temporality, they show how students' look at their future and how they conceive it over the long-term through the successive achievement of predefined steps (like climbing a ladder). Most students never mentioned their careers when we asked them about the impact of the strikes. Others laughed about these "risks". Instead, students valued the "here and now" because this is where and how they self-realize. These moments came to define their whole life, without consideration for the future. They were totalizing.

When the future was mentioned, it was closely related to what they were doing in the here and now. For instance, they would, speak about how they felt the urge to "be there" to be able to talk about this presence to their future children. In a sense, their future was embodied in the present. This led them to define political change as a series of "experiential victories" grounded as a part of various individual daily rhythms. Non-linear, cumulative, and simultaneous change was associated with liberation and power.

\section{Feeling the city in strike: affects}

These multiple situations of action were filled with intense emotions related to the unfolding of actions but also to the many other situations in which the person is involved at other moments of daily life: work, intimate relations, studies, family, and so on. This is where the biometric data became very useful because it enabled the person to speak about why they experienced a strong emotion in a specific place, regardless of whether or not it was related to the formal topic of the interview. In other words, in a traditional interview, the person may describe emotions felt in their encounter with the police, but would not have spoken about other aspects of their life because they would filter that out as irrelevant to an interview about their political involvement in the student movement. However, biometric data opened enough space to speak about these moments and their interrelations, which brings us closer to the actual experience of the person. Consider this example:

Quincy: And as we were walking to one of the apartments, I realized it was right in front of the spot. So I started talking about like space, and I started talking about the violence that I fear being out in that regard, or people knowing that I came out and that I'm not in a monogamous relationship. But that you know I'm open to same-sex interactions. And then we ended up like going to their apartment and dancing and I was a little bit high. I smoked some weed. And then my friend, another guy, he had been very interested in what I was saying, and I started getting the impression that maybe he, like he and I had a connection. So that maybe he was going to like reveal something to me about how he felt about me, but I didn't really feel ready for that so as we were leaving, we were having this sort of conversation... but not really, you know?

\section{Interviewer: yeah}

Quincy: it was kinda like beating around the bush and there was a palpable tension, like sexual tension. And as he left a van came by and they yelled "fucking faggots"

\section{Interviewer: ahhhh}

\section{Quincy: yeah}

Interviewer: and this happened how long before we met here?

Quincy: this was, no this was, yeah this was about a week before we met.

In this excerpt from our second interview, Quincy interprets his biometric data. The peak occurred when we were standing in front of a college. During the first interview, standing where students had erected a barricade, Quincy spoke to us about how ambivalent he felt towards the use of violence in political action. 
Standing there provoked a strong affective charge, which, as we learned in the second interview, was not explicitly related to what we were talking about (the violence of the barricade) but to this specific place, where he had experienced an intense moment just a week before we met. However, his sexual and political experiences were intertwined in his analysis:

Quincy: yeah, and I ended up chasing after them on my bike, and um and this is where all of this was like playing out in my head: the idea of like, I was being victimized, I was being othered, I was being hurt, trying to be hurt and how am I going to answer to that. You know? But I like became enraged and I started to chase after the van. They were stopped at a red light and I pulled up next to the window passenger, and I looked in and I probably looked kind of nuts (I had a big beard at this point). And um, I looked in and I saw this sixteen-year-old boy, you know, and when he saw me looking in the window he went like: ah aha ah (making distress sounds). And he went like: "it's the guy on the bike" "it's the guy on the bike" (imitates terrified voice) it's the guy on the bike, it's the guys on the bike, it's the guy on the bike" and like I saw his soul, you know, I was still a bit high, but I could see like that I had totally inverted the like...

Interviewer: power relation?

\section{$(\ldots)$}

Quincy: like, so like all this has been going on through my head. So you know when we talked about this, and like just the idea of like, you know, when you said it now: the violence can be a peaceful act, it was like pfft, (imitates crashing sound or two things hitting each other) Wow! Violence, a peaceful act. I don't know, you know, but like having just come out of this experience, it's like well what's violence, and you know do we need to stand out? And how do we do it skillfully? How do we do it respectfully? Peacefully? You know? Yeah.
The intertwining between the intimate and the political can be explained by the feeling of living in a suspended time and space, in a sort of rupture with the past. Studies on carnivals illustrate this very well. The "strike city" was experienced as a moment where rules no longer mattered. What mattered was the empowering feeling of the here and now. Our data is filled with these examples. These modes of action are generally ignored by the sociology of social movements because it focuses on strategic actions. These multiple gestures are nevertheless what constitute political action and what invite people to engage.

\section{Walking the city: space during and after the strike}

If we were to identify a collective actor for this period, it would be the "walker," because "walking is demonstrating, but it is also marching towards change." (Fortin, 2013: 518, our translation). The street weighed heavily on the mental maps produced by the respondents. It served to relate significant places and composed a reticular conception of space. Béatrice explains "I knew these places because I always came by subway, but you know the conception of space, the conception you have of space, it's like little floating pieces. You can put them on a map, but you can't see the progression between places because you don't cross them on foot."

The vast majority (19) of the mental maps produced depict a reticular conception of space, whereas four of them would be best described as a mosaic of disconnected places and three as a circuit in which the streets themselves being predominant with no real identification of specific points. The experience of walking the city during demonstrations and other activities helped the respondents to "connect" their significant places into a network. This reticular conception of space is also typically very temporally dynamic. For instance, Hubert expresses how various moments and places hold relative significance:

Hubert: I think that it is a candid observation to realize how much everything is superimposed and continues simultaneously, you know. That as some people are thinking 
they are going to die from the tear gas, others are buying Pop Tarts. There is no universal cohesion where everything occurs at the same time. Nothing stops because something is happening. The Earth continues to turn. Fukushima continues to send radioactive substances in the ocean. There is no rupture, just never.

In this superposition of moments and places, respondents would construct "mental maps of activism," to use Alain's own words. Or as Christine would say, "It is super interesting to see the city become a sort of map for, you know, guerilla strategies (laughter). I'll use the term guerilla, I don't know what else to use. But you know, observe the city through an angle." Space is valued strategically according to its risk potential, or more often, according to a feeling of belonging or the ideological value with which it is associated.

With the biometric data collected and the interpretation provided by the interviewees during the second interview, we mapped the most significant places in Montreal for students, using a color-coding system to identify each place associated with specific emotions (friendship, empowerment, solidarity, fear, feeling of rejection, safety). These places are concentrated in four areas of the city. The first and most important location is near Place Émilie-Gamelin (a small plaza adjacent to the militant French-speaking University of Québec in Montreal - UQAM). Most students felt strong emotions at this location. The plaza was, and still is, the main gathering point for marches and protests in Montreal. The emotions associated with this location are strongly positive: empowerment and friendship. The second most important location is the downtown business district and Congress Centre. Here, students expressed fear and insecurity because it was the site of violent confrontations with the police. However, empowerment and solidarity were also commonly expressed for this zone (Figure 2).

The third location is near McGill University, Montreal's most well-known English-speaking university. The distribution of emotions here is similar to what we see near the Congress Centre, but participants felt much less fear and more solidarity. The experience of students who supported the strike at McGill was marked by important interpersonal conflicts with their fellow students who largely rejected the strike. Our respondents expressed significantly negative experiences on picket lines for that reason.

The last important area is the Berri Street tunnelas previously mentioned by Quincy. The "tunnel" is in fact an overpass on top of a small hill where thousands of people would walk during the marches. Protestors were able to look back and admire the size of the crowd as they climbed the hill and feel the vibration of their exhilarating screams when passing through the tunnel. Here, respondents shared feelings of solidarity and pride. Most interviewees identified these moments as key to the persistence of their engagement.

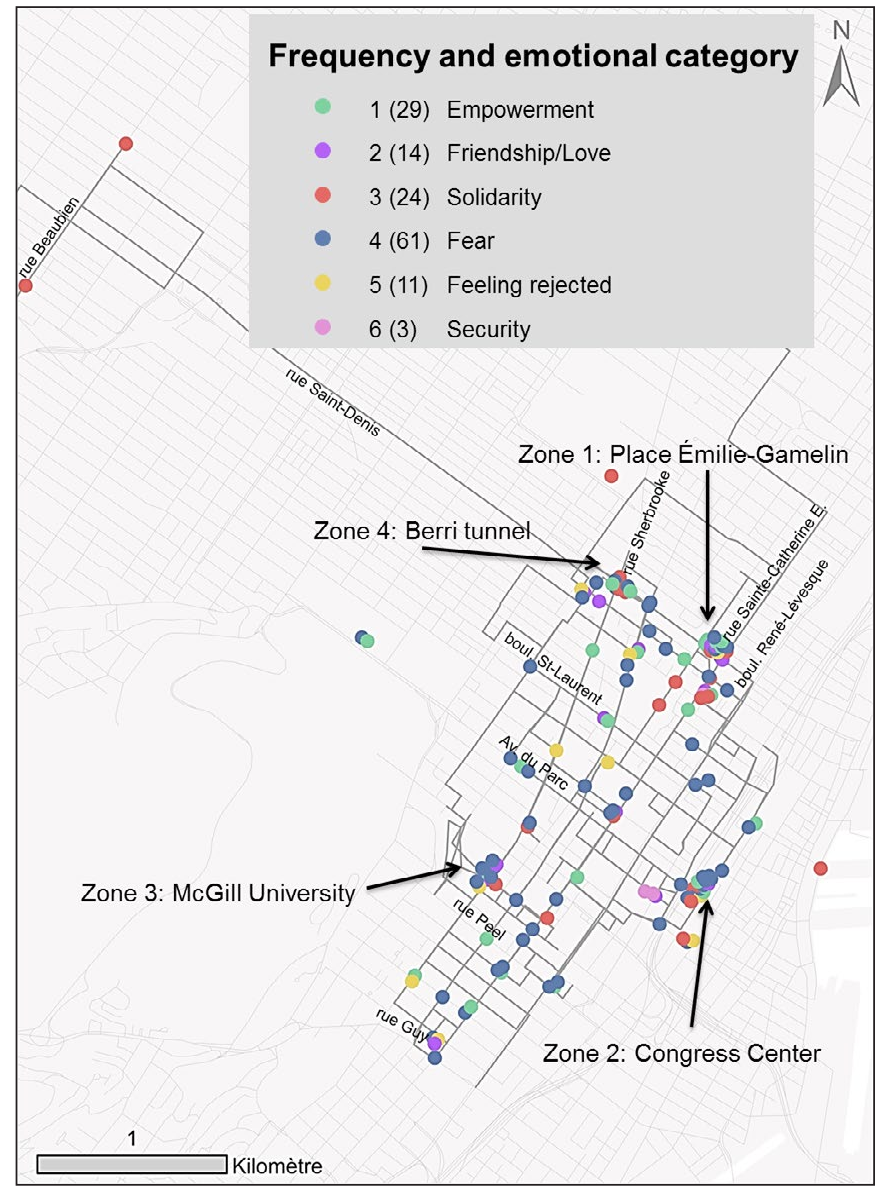

Figure 2. Significant places and related emotions

These places were significant to the students because this is where they felt their engagement most strongly, but also because they frequently went there 
over the eight months of the strike. These spatial routines, including the "illegal" demonstrations every night at $8 \mathrm{pm}$ starting at Émilie-Gamelin over more than 100 days, or the daily sounds of pots and pans on the balconies and residential streets at $8 \mathrm{pm}$, were efficient disturbance strategies (Sewell Jr., 2001). Many news articles evoked the business owners and other economic actors' worries about the temporary functional displacement of the city's economic spaces. Restaurant owners, for instance, complained about reduced business during the strike.

However, beyond the efficiency of these spatial routines, our research reveals how the intensity of feelings in these places affects the students' relation to the city even a year after the strike. It has affected how they move about the city, preferring to walk, avoiding subway cars when they see police officers because they still feel "traumatized" or "angry" to use their words. It has effected where they go and how they get there. Most felt it changed their feeling of belonging with the city. For instance, as we were walking near the Place des Arts during our interview, we asked Roger how he felt about the fact that many tourists were now standing in the same location for the Montreal Jazz festival without a clue about what had happened there a year before. He responded without hesitation "This is mine. Montreal is mine now." The feeling of spatial appropriation was strong among almost all participants.

We then asked the students whether they saw themselves building their lives in Montreal and whether their engagement in the 2012 actions played a role in this decision, most said that the connection confirmed their desire to stay in Montreal. As Christine would say: "it just reconfirmed, it just reconfirmed that Montreal was my, my headquarters. It was my headquarters and I will always come back (laughter)."

With this question, we wanted to encourage respondents to speak about urbanity, to articulate through words what we had been exploring differently throughout our meetings (time, space, affect). They responded in three ways: yes, I want to live in Montreal, without a doubt; I want to live in a large city but I don't know which one; and I want to live in the countryside while being in Montreal.

Most respondents wanted to live in "the city", in Montreal or elsewhere. But eight of them expressed a desire for the "countryside" without leaving the "city". We used quotation marks here because such dichotomies are difficult to sustain in an urban world (Brenner, 2013). Indeed, the "countryside" as described by these interviewees is urban because it is lived reticularly with the city, on a non-linear temporality and through an affective relation to the world. Fred expresses this as follows:

No doubt that Montreal will always stay at the core of my life. But it is just that we need a relief valve because it has become a little hard. Rapid gentrification, too many cars. It's stressful you know. But at the same time, I am involved on the community level. It's just that there's space outside of the city where you can breathe a little. At the same time, I see myself in a co-op in Montreal for instance, with friends. Getting into that kind of thing.

Fred rejects urban planning and its problems, but not urban living. He desires urbanity even if he wants to "work the land" and "have chickens and pigs." Fred, Ivan, Wadji, Hubert Xenia, Jacques, Téa and Victor envision an alternative urbanity. They speak of a world in which the "city" and the "countryside" are strongly are connected to their political, cultural, and social practices. Urbanity for them has "something wild, which is not domesticated you know, which you can't put in a park with a fence and that will stay there, you know." In this excerpt, Hubert speaks of skateboarding as a metaphor to describe his political engagement and his worldview. We could say that he is also describing urbanity.

\section{Conclusion}

Because of a changing relation to time, space, and affect, these small incursions into the experience of students who participated in the 2012 student strikes 
in Montreal illustrate that the political process cannot be fully understood if we focus only on power relations between actors. Actions unfold through a sequence of simultaneous situations. This requires looking not only at the actors, but at a sequence of situated gestures. Students insisted that this was a movement without leaders. When we asked them if there were dominant figures, they described anonymous figures such as the crowd, the red square or Anarchopanda (a college professor who always demonstrated dressed as a panda to protest against the police requirement for unmasked faces).

What dominates the respondents' discourse is the feeling of improvisation, tactics and adaptability, much more than the countless hours spent organizing and strategizing. The formal actions of student unions would unfold in direct response to government actions. However, the vast majority of actions over these eight months followed their own logic; the logic of the street. They were not a response to the government, but rather they followed their own temporality and rationality.

The issues at stake and the lines of conflict during this episode of Montreal's history cannot be understood as a simple opposition between the dominators and the subordinated. The spring of 2012 was clearly marked by an ideological battle between the government's neo-liberal projects and the students' social justice projects. But it was not mainly resistance to the neo-liberal ideology that drove their political engagement. This research shows that paying attention to other forms of rationality, using a methodology that brings us closer to a pre-cognitive register, reveals the interconnection between rational political arguments and other spheres of life. Students got involved out of friendship, to self-realize, to confirm their identity, because it was liberating and they felt fulfilled. In other words, the motor of political action largely rests on the intensification of daily positive effects, often more than the ideological battle. We often act out of impulsion more than antagonism. This tends to transpose ideological conflicts onto interpersonal conflicts. It tends to personalize and embody issues that are lived more affectively than cognitively.

\section{References}

Amin, A. 2004. 'Regions Unbound: Towards a New Politics of Place", Geografiska Annaler Series B Human Geography, 86 B (1): 33-44.

Austin, David. 2013. Fear of a Black Nation: Race, Sex, and Security in Sixties Montreal. Toronto: Between the Lines.

Auyero, J. 2004. 'When Everyday Life, Routine Politics, and Protest Meet", Theory and Society, 33 (3-4): 417-441.

Bauman, Z. 2005. Liquid Life, Toronto: Wiley.

Boudreau, J.-A. 2009. "Taking the Bus Daily and Demonstrating on Sunday: Reflections on the Formation of Political Subjectivity in an Urban World”, CITY, 13 (2-3): 336-346.

Brenner, N. 2004. New State Spaces. Urban Governance and the Rescaling of Statehood, Oxford: Oxford University Press.

Brenner, Neil. 2004. "Urban governance and the production of new state spaces in western Europe, 1960-2000" Review of International Political Economy. Vol. 11(3): 447-488.

Brenner, N. 2013. "Theses on Urbanization", Public Culture, 25 (1): 85-114.

Castells, Manuel. 1973. Luttes urbaines et pouvoir politique. Paris: Maspero.

Castells, Manuel. 1983. The city and the grassroots. Berkeley and Los Angeles: University of California Press.

Chiasson-Lebel, T. 2012. " Introduction. Grèves et tensions dans les universités et les cégeps. "Nouveaux cahiers du socialisme, Éducation supérieure culture, marchandise et résistance, 8: 1-7. 
Cox, Kevin R. 1998. "Spaces of dependence, spaces of engagement and the politics of scale, or: looking for local politics" Political Geography. 17 (1): $1-23$.

Deverteuil, G. 2014. 'Being Poor in the City", In Paddison, R. and McCann, E. (Eds.) Cities and Social Change: Encounters with Contemporary Urbanism, London: Sage Publications, 56-74.

Diaz-Parra, I. and Candon Mena, J. 2015. "Squatting, the 15-M Movement, and Struggles for Housing in the Context of the Spanish Social Crisis", Human Geography, 8 (1): 40-53.

Dupuis-Déri et al. 2013. À qui la rue? Répression policière et mouvements sociaux, Montréal: Écosociété.

Fainstein, S.S. and N.I. Fainstein. 1985. "Economic restructuring and the rise of urban social movements" Urban Affairs Quarterly. Vol. 21(2): 187-206.

Fontan, J-M., P. Hamel and R. Morin. 2012. Villes et conflits. Actions collectives, justice sociale et enjeux environnementaux, Québec : Presses de l'Université Laval.

Fortin, A. 2013. "La longue marche des Carrés rouges" Recherches sociographiques, 54 (3): 513-529.

Goffman, E. 1959. The Presentation of Self in Everyday Life, New York: Anchor Books.

Goodwin, J. and Jasper, J.M. 2006. 'Emotions and Social Movements", In Handbook of the Sociology of Emotions, Stets, J. and Turner J. (eds.), Springer: US, 611-635.

Harvey, David. 1985. The place of urban politics in the geography of uneven capitalist development. The urbanization of capital. Baltimore: The Johns Hopkins University Press.

Helman, C. 1987. The Milton-Park Affair: Canada's Largest Citizen-Developer Confrontation, Montreal: Vehicule Press.
Hosany, S. et al. 2015. 'Measuring Tourists' Emotional Experiences: Firther Validation of the Destination Emotion Scale", Journal of Travel Research, 54 (4): 482-495.

Jasper, J.M. 2011. "Emotions and Social Movements: Twenty Years of Theory and Research", Annual Review of Sociology, 2011 (37): 285-303.

Jessop, Bob. 1990. State Theory: Putting the Capitalist State in Its Place. Penn State Press.

Labrie, M. 2015. «Mouvement étudiant du printemps 2012 au Québec: exploration du répertoire d'action mobilisé», Métropoles [En ligne], 2015 (16): http://metropoles.revues.org/5118.

Lefebvre, H. 1970. La révolution urbaine, Paris: Éditions Gallimard.

Lynch, K. 1960. The Image of the City, Cambridge: The MIT Press.

Magnusson, Warren. 2011. Politics of urbanism: Seeing like a city. Milton Park: Routledge.

Martin, É. 2013. «Le printemps contre l'hégémonie: la mobilisation étudiante de 2012 et le blocage institutionnel de la société québécoise», Recherches sociographiques, 54 (3): 419-450.

Manzo, L.C. 2003. 'Beyond House and Haven: Toward a Revisioning of Emotional Relationships with Places", Journal of Environmental Psychology, 2003 (23): 47-61.

Mills, S. 2011. Contester l'empire: Pensée postcoloniale et militantisme politique de Montréal, 1963-1972, Montréal: Hurtubise.

Munn, N.D. 1992. 'The Cultural Anthropology of Time: A Critical Essay", Annual Review of Anthropology, 21: 93-123.

Pickvance, C. 1984. "The rise and fall of urban movements and the role of comparative analysis" 
Environment and Planning D: Society and Space. Vol. 3(1): 31-53.

Savard, A. and Cyr, M-A. 2014. «La rue contre l'État: Actions et mobilisations étudiantes en 2012» In Ancelovici, M. and Dupuis-Déri, F. (dirs.), Un printemps rouge et noir, regards croisés sur la grève étudiantes de 2012, Montréal: Les Éditions Écosociété, 59-86.

Sewell Jr., W.H. 2001. "Space in Contentious Politics" In Aminzade, R.R., Goldstone, J.A., McAdam, D., Perry, E.J., Sewell Jr., W.H., Tarrow, S. and Tilly, C., Silence and Voice in the Study of Contentious Politics, Cambridge: Cambridge University Press, 59-88.

Sheller, M. and Urry, J. 2006. "The new mobilities paradigm", Environment and Planning A, 38 (2): 207-226.
Simard, M. 2013. Histoire du mouvement étudiant québécois 1956-2013, Ste-Foy: Presses de l'Université Laval.

Stolle, D., Pedersen, E.F., Harell, A. and Dufour, P. 2013. "Le printemps érable et l'élection québécois de 2012 " In Bastien, F., Bélanger, É. and Gélineau, F. (dirs.), Les Québécois aux urnes; les partis, les médias etl es citoyens en campagne, Montréal: Les Presses de l'Université de Montréal, 271-283.

Toffler, A. 1970. Future Shock, New York: Bantam Book.

Virilio, P. 1986. Speed and Politics, New York: Semiotext(e).

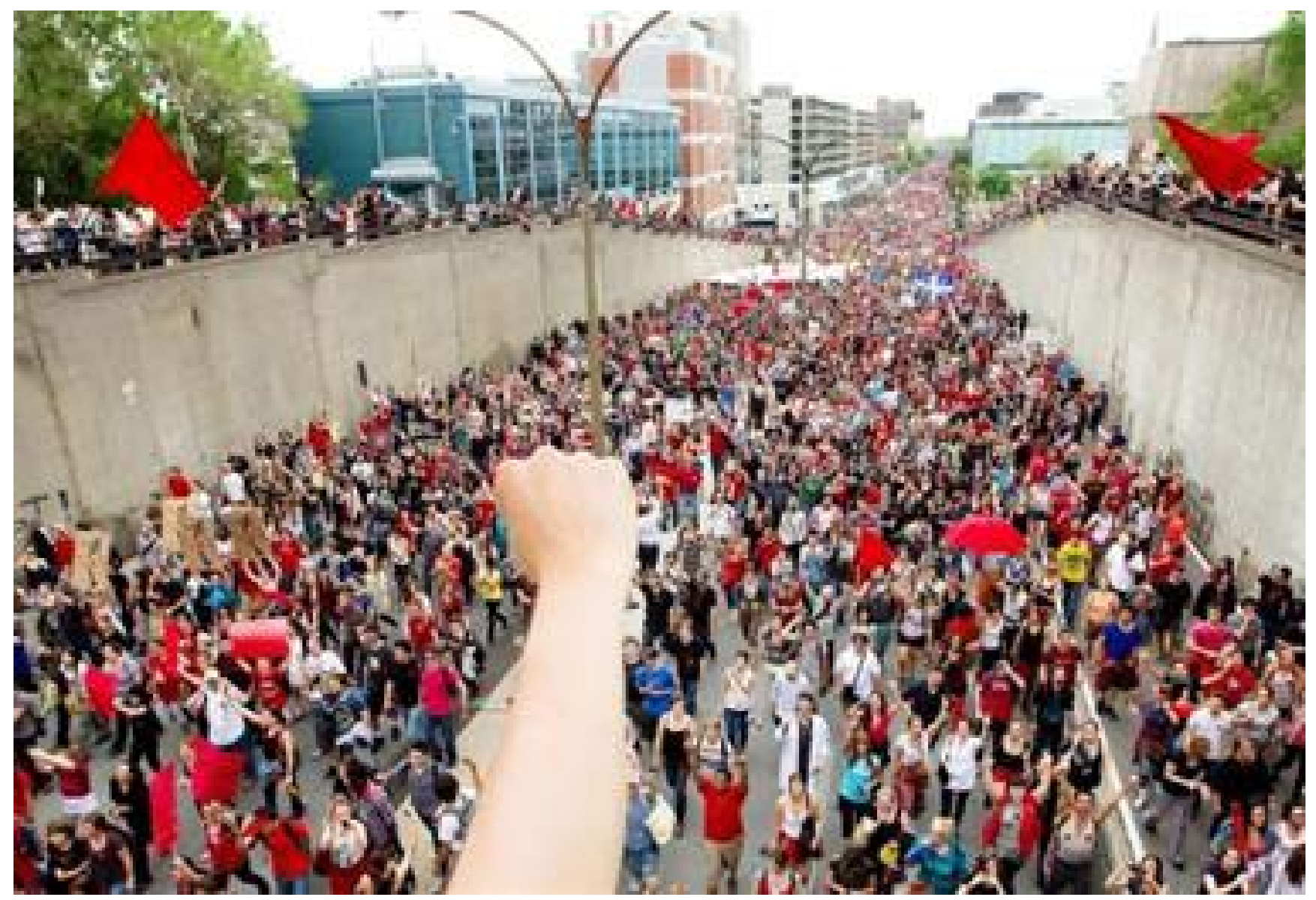

